\title{
THE AVIRULENCE OF THE CULTIVATED PF STRAIN OF TRYPA- NOSOMA CRUZI. V - THE EVALUATION OF PARASITOLOGIC TESTS AFTER VACCINATION OF DIFFERENT ANIMAL SPECIES.
}

\author{
Humberto Menezes (*) e Rosa Ribeiro (**)
}

\begin{abstract}
After vaccination with the live PF strain of Trypanosoma cruzi, 194 blood cultures were performed in 143 mice, 9 dogs, 5 Cebus monkeys and 7 human subjects.

Some of these blood cultures were simultaneously done with xenodiagnosis, subinoculation in baby mice and/or culture of viscerae.

The trypanosomes isolated from the few positive cases $(6,1 \%)$ were incapable of infecting baby mice were considered as cases of immunotolerance. All the other tests were negative.
\end{abstract}

This work intends to demonstrate through blood cultures, xenodiagnosis, subinoculations and culture of viscerae, the avirulence of the $P F$ strain of Trypanosoma cruzi $(20)$ in laboratory animals and humans $(6,8,12,18)$.

\section{MATERIAL AND METHODS}

The majority of animals described in this communication have already been used in several experiments performed in the iast four years by one of us $(6-20)$, a common face being that all of them had been vaccinated with the $P F$ strain with the doses mentioned in Table 1.

They later had blood culture with or without one or several of the tests specified above.

164 animals were used; 143 white mice, 9 dogs, 5 Cebus monkeys and 7 human beings in which 194 blood cultures were performed.

The culture medium used was that of Warren, as described by one of us (1). The tests were realized $8,15,20,30,45,60,90$, $120,150,180,270$ and 510 days after vaccination. In some groups tests were made only once in one of these periods but in others in more than one period or in all of them as was the case with the human subjects.

Among the mice than had only blood cultures, the amount of total blood or serum used was 0,4 to $0,7 \mathrm{ml}$ for each test tube of culture medium.

When more than one test was performed on mice, that amount was only $0,2 \mathrm{ml}$. In human subjects, dogs and monkeys, the quantity of total blood or blood serum (the later in accordance with Strout's technique-23) was always $0,5 \mathrm{ml}$ for each test tube.

The results of the blood cultures were always recorded on the 30 th. day as a blind test since the technician had no knowledge of the origin of the material under examination.

The xenodiagnosis wad done by the use of 4 th. instar nymphes of Rhodnius

* USP. Faculdade de Medicina de Ribeirão Prêto. São Paulo. Brasil.

* Departamento de Ciências Biológicas. Fac. Far. Odont. Ribeirão Prêto.

Recebido para publicação em 14-12-1971. 
prolixus or Rhodnius neglectus in the laboratory animals, and 5th. instar nymphs of Panstrongilus megistus or Triatoma infestans in the humans.

The triatominae sucked the blood of the animals for 20 minutes and were examined also as a blind test, one month later.

The subinoculations in young mice were generally performed using heparinized blood, but sometimes centrifuged blood serum was used as for the blood cultures.

The inoculum was 0,1 or $0,2 \mathrm{ml}$ always injected intraperitoneally.

The inoculated animals had their peripheral blood searched for parasites, by the Pizzi-Brener technique (2), 8,15 and 30 days later, with the exceptions mentioned in Table 1.

Among these exceptions were the cases of successive subinoculations when the animals of each group were bled to death by heart punction 8 days after vaccination or inoculation of positive blood culture. From the blood pool of the first group the serum was separated, centrifuged and injected in a new group and so on.

The cultivation of viscerae was done in the same Warren medium. Under asseptic conditions, fragments of heart, liver and spleen were kept and triturated in sterile saline solution containing 1000 IU of $\mathrm{Pe}-$ nicillin and $1000 \mathrm{ug}$ of Streptomycin per $\mathrm{ml} .0,5 \mathrm{ml}$ of the triturate were transfered to each tube of culture medium.

A group of 18 vaccinated mice had blood culture 30 days after challenge with a virulent strain which, with the same inoculum, killed $100 \%$ of the control animals.

Two dogs out of 5 vaccinated with a very large number of $P F$ parasites presented positive blood cultures 21 days after vaccination. As described in the Table 1 these cultures were inoculated into young mice with negative results.

One month after vaccination the 5 dogs were challenged with the $Y$ virulent strain. Thirty and sixty days later the blood cultures of all the animals were negative while $75 \%$ of the control dogs had died.

\section{RESULTS}

From the 194 blood cultures realized only 12 , i.e., $6,1 \%$ gave positive results.
The positive cases can be summarized as follows:

1) - Seven mice with $10 \mathrm{~g}$ of body weight that had received, previous to vaccination, Vinblastin sulphate injections. The positive blood cultures were injected successively into three groups of young mice, with negative results.

2) - Two dogs out of 5 that received very large inoculum as already mentioned.

3) - One mouse from a group of 4 that, before vaccination, had received a high dosage of Prednisolone. Eight mice inoculated with the positive blood culture presented no parasitemia until the 30 th day of inoculation.

4) - Two mice out of 5 that received a very large number of $P F$ parasites had positive blood cultures 15 days after vaccination. As in the previous cases the injection of these cultures in young mice were negative.

Of the 143 vaccinated mice, 5 had, simultaneously, blood culture, xenodiagnosis, culture of viscerae subinoculation, negative 8 days after vaccination.

Another 5 animals had only bood culture, subinoculation and xenodiagnosis, with the same result, 15 days after the vaccination.

Ten mice, 5 treated previously with Azathioprine and 5 with Methotrexate, had negative blood culture and subinoculation 15 days after receiving the $P F$ vaccine.

One group of 22 mice that had previously begun treatment with a low dosage of Prednisolone and continued it until 30 days after vaccination, presented at this time negative cultures of blood and viscerae.

The other vaccinated mice had only blood cultures, all of them negative as described in Table 1.

Blood cultures and xenodiagnosis were done on the 5 Cebus monkeys, 3 on the 30th, 1 on the 90th day and 1 the 180th day after the vaccination, all presenting negative results.

In human subjecis the tests applied were blood cultures, xenodiagnosis and subinoculation in mice. 
TABLE

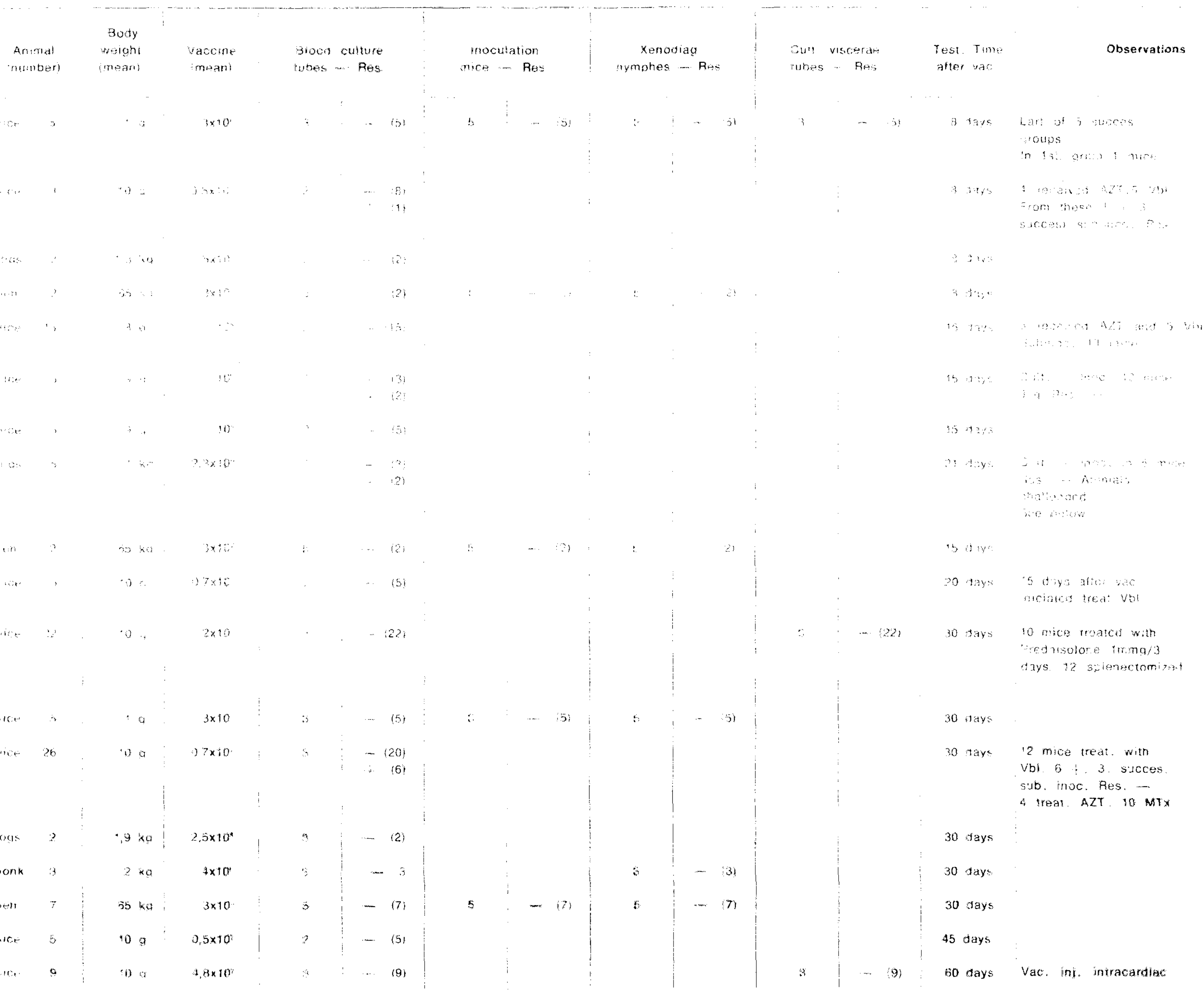




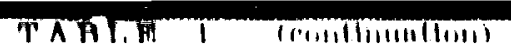

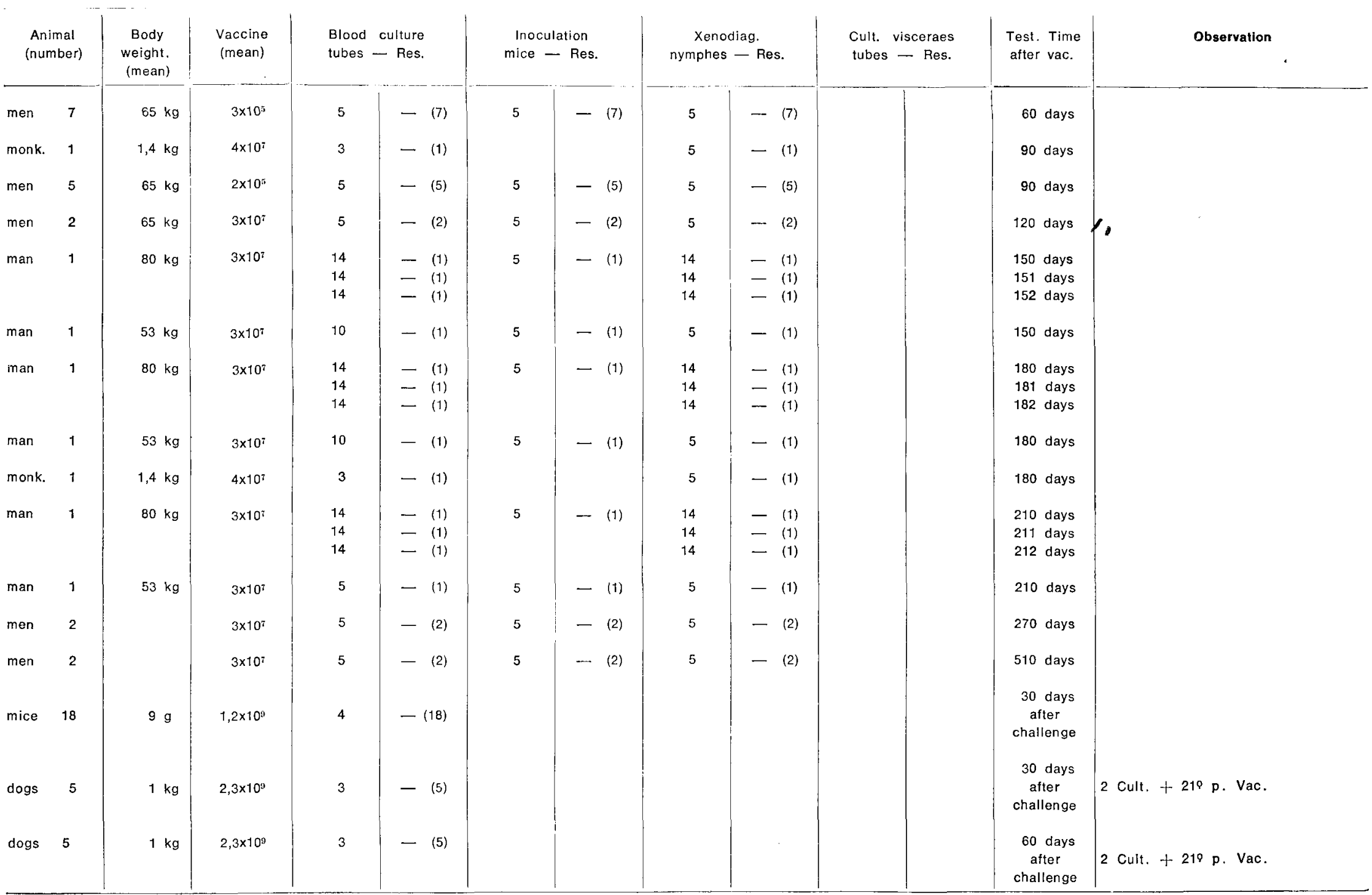


One of the seven human volunteers had xenodiagnosis in the 5th. 6th. and 7 th. month post-vaccination, following Schenone's technique (22).

At the same time, blood cultures were done, employing 1 tube of culture to each triatcma bug, i.e., 14 tubes every day for 3 successive days and 3 successive months.

All the tests done on the human subjects were negative.

\section{DISCUSSION}

It is not our intention to make any critical analysis of the value of the parasitologic tests in the diagnosis of trypanosomiasis infection.

To those interested in the subject we recommend the papers of Pedreira de Freitas (5), Chiari \& Brener (4) and Albuquerque (1).

The later has demonstrated that mice with chronic $T$. cruzi infection gave $61,7 \%$ positive blood cultures. This percentage rose to $90 \%$ when cultivation of heart triturate was made simultaneously.

Although this paper has been written with the aim of showing the avirulence of the $P F$ strain by the negativity of the parasitologic tests, we think that their importance remains in the analysis of the positive results.

As one of the researchers has already observed $(12,13,15)$, it is possible under certain special conditions to obtain positive parasitemias and /or blood cultures from vaccinated animals.

In the 194 blood cultures realized, only $6,1 \%$ gave positive results.

This is a very low value but would be enough to challenge our assertion that the $P F$ strain is avirulent if the positivity of the culture had represented a real diseaseinfection of the animals or a restoration of the primitive virulence of the cultivated strain.

In another work, one of the authors
(19) has discussed this subject and demonstrated that all the positive results can be explained as a phenomenon of immunotolerance, since in the absence of the peculiar circunstances that induce this phenomenon, all tests sooner or after vaccination were always negative.

No vaccinated animal, even those with positive blood cultures or those challenged with virulent strain, died from trypanosoma infection.

The trypanosoma isolated from the blood cultures were unable to infect young mice $(13,19)$.

Santos (21) have shown that the $P F$ strain is incapable to infect too the invertebrated host of the parasite.

Is is worth emphasizing that even with the use of immunosuppressor agents the parasitemia was always negative and no subinoculation was positive and no parasites were detected in the tissues of the positive blood culture vaccinated animals $(7,9,10)$.

As already demonstrated (11) inocula of $10^{3}$ live parasites of the $P F$ strain were sufficient to confer immunity to mice of $10 \mathrm{~g}$ body weight.

The use in normal animals of doses $10^{5}$ times greater always showed negative blood tests which for us represents good evidence of the evirulence of the strain and the broad safety margin of the vaccine.

It is an elementary rule of Preventive Medecine that nobody under the action of immunodepressor drugs (3) or under immunoparalysis inducing circunstances should be actively vaccinated. The $P F$ vaccination should not be excluded from this rule.

Except in special positive cases which can be considered as cases of immunitolerance, we can conclude that the $P F$ strain of Trypanosoma cruai is avirulent for men and animals on the basis of the parasitologic tests here mentioned.

\section{RESUMO}

Após vacinação com a cepa PF do Trypanosoma cruzi, 194 hemoculturas foram feitas em 143 camundongos, 9 cães, 5 macacos Cebus e 7 homens.

Algumas dessas culturas foram realizadas simultaneamente com xenodiagnóstico, subinoculação em camundongos jovens elou cultura de visceras (coração, fígado e baço). Raras hemoculturas foram positivas $(6,1 \%)$, mas os demais testes foram negativos. Os tripanosomas isolados dos casos positivos fo- 
ram incapazes de provocar infecção quando inoculados uma ou mais vezes em camundongos jovens. O fenômeno só ocorreu em certas e determinadas circunstâncias consideradas como indutoras de imunotolerância.

\section{REFERENCES}

1. ALBUQUERQUE, R. D. R. - Estudo comparativo entre o valor dos xenodiagnósticos seriados e o das culturas de sangue e de triturados de órgãos para o diagnóstico da tripanossomose americana experimental na fase crônica. Tese. Fac. Farm. Odont. Rib. Preto, 1968 .

2. BRENER, Z. - Contribuição ao estudo da terapêtica experimental da Doença de Chagas. Tese. Fac. Farm. odont. Univ. M. Gerais. B. H., 1961.

3. BIANCHI, H. - Imunizações: condutas práticas. In Doencas transmissiveis. V. Amato Neto \& J. L. Baldy Edts. Liv. Ateneu, S. Paulo, 1972.

4. CHIARI, E. \& BRENER, Z. - Contribuição ao diagnóstico parasitológico da Doença de Chagas na sua fase crônica. Rev. Inst. Med. trop. S. Paulo. 8: 134-138, 1966 .

5. FREITAS, J. L. P. - Contribuicão para o estudo do diagnóstico da Moléstia de Chagas por processos de Laboratório. Tese. Fac. Med. Univ. S. Paulo., 1947.

6. MENEZES, H. - Protective effect of an avirulent (cultivated) strain of Trypanosoma cruzi against experimental infection in mice. Rev. Inst. Med. trop. S. Paulo. 10: 1-4, 1968.

7. MENEZES, H. - Lesões histológicas em camundongos "vacinados" com uma cepa avirulenta de Trypanosoma cruei. Rev. Bras. Med. 25: 160-165, 1968 .

8. MENEZES, H. - Active immunization of dogs with a non virulent strain of Trypanosoma cruzi. Rev. Inst. Med. trop. S. Paulo. 11: 258-263, 1969.

9. MENEZES, H. - Lesões histológicas do coração em cães "vacinados" com uma cepa avirulenta de Trypanosoma cruzi. Rev. Bras. Med. 26: 281283, 1969 .

10. MENEZES, $\mathbf{H}$. - Cardiac and hepatic lesions in laboratory animals immunized with an avirulent strain of Try- panorosa cruzi. II Cong. Panam. Int. Acad. Pathol. Buenos Aires 26/11/ 1969.

11. MENEZES, $H$ - Imunização de camundongos com "vacina" viva avirulenta de Trypanosoma cruzi. I - Ensaio da avaliação do menor inóculo eficiente, Rev. Soc. Bras. Med. Trop. 3: 297-303, 1969.

12. MENEZES, H. - I - The avirulence of the cultivated $\mathrm{Y}$ strain of Trypanosoma crusi. Rev. Inst. Med. trop. S. Paulo, 12: 64-68, 1970.

13. MENEZES, $\mathrm{H}$. - II … The avirulence of the cultivated $\mathrm{Y}$ strain of $T$. cruzi. Rev. Inst. Med. trop. S. Paulo. 12: 129135,1970 .

14. MENEZES, H. - III - The avirulence of the cultivated $Y$ strain of $T$. cruzi. Rev. Inst. Med. trop. S. Paulo. 13: 14$17,1971$.

15. MENEZES, $\mathrm{H}$. - The avirulence of the cultivated $\mathrm{Y}$ strain of Trypanosoma cruai. - IV - The effect of immunosupressive agents in mice. Rev. Soc. Bras. Med. Trop. (in press).

16. MENEZES, H. - Aplicação de vacina viva avirulenta de Trypanosoma cruzi em seres humanos (Nota prévia). Rev. Inst. Med. trop. S. Paulo. 13: $144-154,1971$.

17. MENEZES, $H$. - The vaccination of human being with live avirulent vaccine of Trypanosoma cruzi. A one year follow-up of the first two cases. Hospital (in press).

18. MENEZES, $\mathrm{H}$. - The vaccination of a new group of human volunters with live avirulent strain of Trypanosoma cruzi. Under publication.

19. MENEZES, H. - Imunização ativa contra a tripanosomose sulamericana. Síntese da nossa experiência. Rev. Bras. Med. (in press).

20. MENEZES, $H$. \& ALBUQUERQUE, $R$. D. R. - Imunização de camundongos com "vacina" viva avirulenta de Trypanosoma cruzi. - III - Variacão do meio de cultura. Rev. Soc. Bras. Med. Trop. 4: 69-74, 1970 
21. SANTOS, J. C. M. - Comportamento da cepa avirulenta PF do Trypanosoma cruzi no hospedeiro invertebrado. Rev. Inst. Med. trop. S. Paulo. 13: 279-284, 1971.

22. SCHENONE, H.; ALFARO, E.; REYS, H. \& TAUCHER, E. - Valor del Xe- nodiagnostico en la infeccion chagasica cronica. Boll. Chil. Parasit. 23: 149-153, 1968.

23. STROUT, R. G. - A method for concentrating hemoflagellates. J. Parasit. 48: 100,1962 . 